\title{
HUMAN GENETICS IN WORCESTERSHIRE AND THE SHAKESPEARE COUNTRY
}

\author{
I. MORGAN WATKIN \\ County Health Department, Aberystwyth
}

Received 7.x.66

\section{INTRODUCTION}

THE western limits of Worcestershire lie about thirty miles to the east of Offa's Dyke-the traditional boundary between England and Wales -yet Evesham in the south-eastern part of the county is described by its abbot in a petition to Thomas Cromwell in I 539 as situated within the Principality of Wales. The Star Chamber Proceedings (No. 4) in the reign of Henry VII refer to the bridge of stone at Worcester by which the king's subjects crossed from England into Wales and the demonstrations against the Act of 1430 regulating navigation along the Severn were supported by large numbers of Welshmen living on the right bank of the river in Worcestershire.

The object of the investigation is to ascertain whether significant genetic differences exist in the population of Worcestershire and south-western Warwickshire and, in particular, whether the people living west of the Severn are more akin to the Welsh than to the English. The possibility of determining, on genetic grounds, whether the AngloSaxon penetration was strongest from the south up the rivers Severn and Avon, or across the watershed from the Trent in the north, or from the east through Oxfordshire and Warwickshire is also explored.

\section{THE COUNTY}

Worcestershire has fluctuated in size over the centuries and Stratford-on-Avon came for a period under its jurisdiction while Shipston-on-Stour, now a Warwickshire township, remained in one of the detached portions of Worcestershire until the turn of the present century. The survey embraces Worcestershire, as defined in 1966 , and south-western Warwickshire, an area which largely corresponds with the northern part of the old Saxon sub-kingdom of the Hwicci.

\section{HUMAN HISTORY}

In Romano-British times the Dobunni held the whole of the Avon valley in Worcestershire and south-western Warwickshire. Although the Ordnance Survey map of Roman Britain shows them as extending to the Wye this, according to Dudley (1966, personal communication), is based on a third-century milestone from the neighbourhood of Kentchester, Herefordshire, on which the letters R.P.C.D. have been taken to mean res publica civitatis Dobunnorum. If this is the reading and its interpretation it is still possible to suppose that an area was 
transferred in the late Empire. The whole distribution of Roman military sites west of the Severn in the first century suggests, however, that this territory was in the hands of the Silures (Dudley and Webster, I 962), the people who occupied most of South Wales and Herefordshire.

The Roman forts at Walltown near Cleobury Mortimer, Shropshire, and at Greens Forge, near Wolverhampton, were very probably in the land of the Gornovii, but what happened in between these points and the Avon valley is a matter of conjecture.

The number of villages mentioned in the pre-Conquest records shows that a large part of Worcestershire and Warwickshire south of the Avon were thickly settled in pre-Norman times, and the Hwicci whom Stenton ( 1947) considers to have been of mixed Anglian and Saxon stock numbered no fewer than seven thousand tribute-paying households.

A Scandinavian element existed in Worcestershire, for in the eleventh century the bishop refers to all the thegns both English and Danish. The system of counting based on units of twelve which prevailed, according to Round (1904), in areas settled by the Danes was not current in Warwickshire, for when the king went to war Leicester sent him twelve burgesses whereas Warwick only sent him ten.

After the Conquest the Normans infiltrated the towns and from the fifteenth century onward the Welsh exerted a steady pressure on western Worcestershire-a pressure which reached its zenith during the Industrial Revolution. In common with Herefordshire and Shropshire, Worcestershire came under the jurisdiction of the Council in Wales and the Marches, and its dissolution in $164 \mathrm{I}$ severed one of the county's last links with the Principality.

\section{PHYSICAL ANTHROPOLOGY}

Beddoe (1885) claimed that the Severn was a distinct ethnological barrier: the contrast between the people who crossed the river to market and the left-bank townsfolk struck him " extremely forcibly". The percentage of persons with dark hair and dark eyes in the rural parts of central Worcestershire was only twenty, but in the north-west of the county it rose to thirty. Eastern Worcestershire had an index of nigrescence which was even lower than that in many of the more easterly parts of England. At Stratford-on-Avon, on the other hand, Beddoe came across a larger proportion of dark hair and a higher degree of nigrescence than in most of the Midlands. This he ascribed to its remoteness from the main foci of invasion, its isolation from East Anglia by the almost impassable Fens, and the protection afforded by the ancient forests such as Arden.

In Worcestershire and Warwickshire the average stature of adult males, according to the Report of the British Association's Anthropometric Committee ( 1883 ), lay between $5 \mathrm{ft}$. 7 in. and $5 \mathrm{ft}$. $7 \frac{1}{2}$ in-a figure higher than in Shropshire, Herefordshire and Gloucestershire, but lower than in the counties of Lincoln, Norfolk and Suffolk. 


\section{LANGUAGE}

No reference to the survival of the Welsh language in Worcestershire has, so far, come to light although the county is exceptionally rich in historical documents. Shrewsbury and Hereford are, however, described as bilingual cities in the seventeenth century while in 1485 , according to Southall (I893), Welsh was spoken nearly if not quite to Gloucester bridge. One might, therefore, have expected the more hilly parts of western Worcestershire to have retained their old language as long as the Forest of Dean, which lies in a similar geographical position - between the Severn and the Wye-downstream in Gloucestershire. At what period Welsh became extinct in the Forest is not certain, but Enderbie (I66I) mentions that the language was still spoken in his time in Gloucestershire although he does not specify where. On the western periphery of the Forest, according to W. P. Price, a native of the locality and a former Member of Parliament for Gloucester, the language was not dead in I83o. The fifth Viscount Torrington, after noting that in $\mathrm{I} 78 \mathrm{I}$ Welsh was as much understood and spoken in Monmouth as English, discovered that six miles inland from the village of Trelleck which lies across the Wye from the Forest of Dean "they understood no more English than my dog".

As no mention is made of the use of Welsh translators or " latimers", when the Worcestershire Domesday Survey was carried out - their use in western Herefordshire was not uncommon and not unknown, according to W. Rees (1962), on church lands to the east of Hereford city-the Welsh language may have become extinct in Worcestershire before the Conquest. Scholars headed by Loth ( 1883 ) thought that Gaulish had given way everywhere in Brittany to low Latin and that Celtic was re-introduced by settlers from south-west Britain in the fifth and subsequent centuries. Falc'hun (1963), however, has shown that low Latin never usurped Gaulish and that the Breton dialect south of the river Blavet in particular is a direct descendant of Gaulish. Welsh may, therefore, have lingered on in the hilly parts of Worcestershire longer than is supposed and the large number of Welshmen referred to in the fourteenth and fifteenth centuries may not all have been recent immigrants from Wales. In certain circumstances awareness of nationality is retained when the old language is lost, as for example in present-day Radnorshire (Mid-Wales) or in southern Scotland.

\section{Dialect}

Sergeantson (1927) has shown that Worcestershire and western Warwickshire fell within the same Middle English dialect zone-the West Midland-and also within its central sub-area.

\section{Place names}

The surviving Celtic element in Warwickshire place names is very small in comparison with that in Worcestershire. But in neither county does one encounter a situation similar to that in parts of western 
Herefordshire, where half the field and farm names and more than half the place names are Celtic in origin. On the other hand, an analysis of the early field names of Worcestershire which has not yet been undertaken might, as Hilton (1966, personal communication) suggests, yield interesting results.

\section{Surnames}

In 1885 , according to Beddoe, 12 per cent. of Worcestershire surnames were Welsh while a further 7 per cent. had a more doubtful origin. The surnames accepted as Welsh (Watkin, 1956) diminished from 22 per cent. in western Worcestershire to 5 per cent. in western Warwickshire, the towns of Worcester and Stratford-on-Avon having I5 and 8 per cent. respectively. During the reign of Elizabeth and James I the parish registers of Alcester record the names ap Lewis, ap Gryffen, ap Rice, and Gwillim, and at Stratford in Shakespeare's time the surname Jones was not only the commonest Welsh name but, according to Williams (1954), the commonest of all surnames. The Welshmen, however, almost invariably married English women. The headmaster of the grammar school in Shakespeare's formative years (1573-79), Thomas Jenkins, was a Welshman. And when the dramatist created a schoolmaster in the person of Sir Hugh Evans in The Merry Wives of Windsor it is probably more than a coincidence that he should have made him a Welshman.

\section{TECHNIQUE}

The blood samples were collected from civilian donors attending the clinics of the National Blood Transfusion Service, Midland Region, in the years $1948-64$ and blood grouping was carried out on both cells and serum. As donors do not resign in equal proportions from each of the four blood-groups, the record cards of those who had, for various reasons, ceased to donate blood as well as the active donor panel were examined.

\section{7. $A B O$ BLOOD-GROUPS}

In Worcestershire and the Shakespeare country as a whole persons with English surnames have higher $A$ and lower $O$ gene frequencies than their Welsh counterparts, but the differences are not statistically significant $\left(\chi^{2}=2.49\right.$ and $\left.\mathrm{P}>0.05\right)$ (table $\mathrm{I}$ ).

$A B O$ blood-groups lend no support to the view that the river Severn is a genetic divide in Worcestershire. The inhabitants of Tenbury and Malvern to the west of the river differ little in their $O$ and $A$ gene frequencies from those of the opposite side at Bromsgrove, Redditch, Droitwich, Evesham and Pershore-towns lying at comparable latitudes. The result holds good whether the observation is made on persons with English $\left(\chi^{2}=0.05\right.$ and $\left.\mathrm{P}>0.05\right)$ or on those with English and Welsh surnames $\left(\chi^{2}=0.52\right.$ and $\left.P>0.05\right)$. 


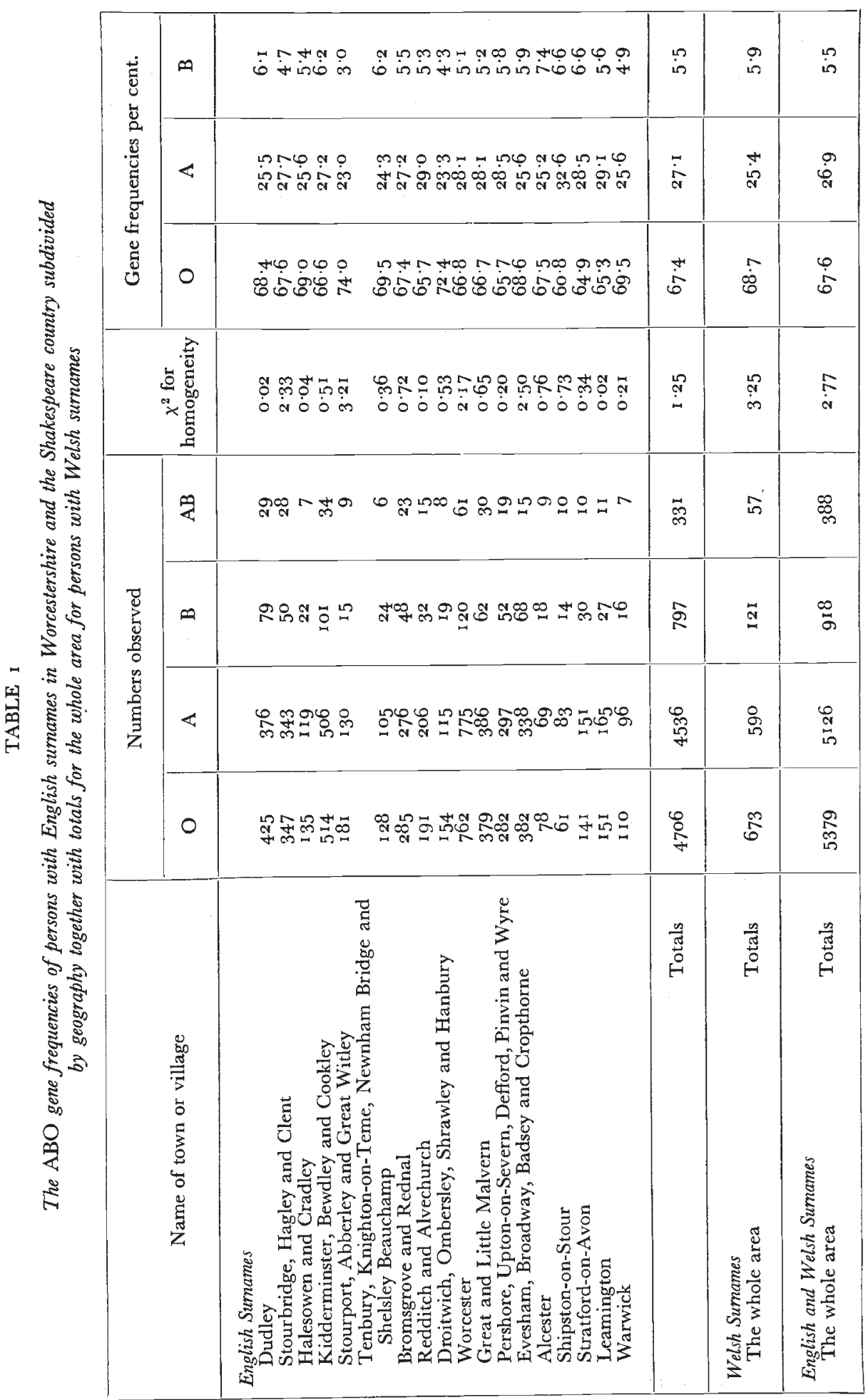


The population of Worcestershire and the Shakespeare country is, however, far from homogeneous with respect to $O$ and $A$. The differences are less clear cut than in Herefordshire where the population to the west of Offa's Dyke and the river Wye exhibits characteristics common to the hill folk of Wales. The three most southerly towns, Worcester, Malvern and Pershore are markedly higher in $A$ and lower in $O$ than the three central Worcestershire towns of Droitwich, Stourport and Tenbury $\left(\chi^{2}=14.5\right.$ and $\left.\mathrm{P}<0.0 \mathrm{I}\right)$ and this genetic divide in mid-Worcestershire may form part of a more extensive line of separation between midland and southern England which is continued in Wales from the Kerry Hills to Gardigan Bay, south of Aberystwyth. Similar genetic divides have been noted along the line of the rivers Humber and Aire and from Durham to Cumberland (Fraser Roberts, 1953).

\section{The $O$ gene frequency}

The high $O$ concentration reaches its zenith at Stourport, a town which did not exist before I 766. A prehistoric trackway (Chitty, I963) extended from the high $O$ areas of Central Wales across the Kerry, Clun, and Clee Hills through Wyre Forest to the river Severn at Bewdley some three miles north of Stourport. Welshmen settled in Worcestershire in considerable numbers before surnames appear to have been generally inherited, and a Welshman's son would probably assume a surname based on his trade or dwelling-place, which suggested purely English connections. The high $O$ influence, though weaker, is discernible in Evesham, and one wonders to what extent it is due to the large numbers of serfs and bondswomen (ancillae) acquired by the monks and other holders of land in Worcestershire in their forays against the Welsh.

The European and Mediterranean distribution of high $O$ points to movement along the western Atlantic seaboard. If Wales is taken as an analogy the high $O$ people of central or lowland Worcestershire were formerly hill folk and it is on the limestones of the Cotswolds, the White Horse Hills, and the chalk downs of Salisbury Plain that their kinsmen are most likely to be encountered. Little is known of the blood-group genetics in what Fox (1959) terms " the best settlement area in Britain in prehistoric times ", but if the connection of the blue stones of Stonehenge with the Preseli Mountains, Pembrokeshire (Thomas, 1923), points to a relationship between the people of the two localities, a high $O$ gene frequency is a mutual characteristic.

The population of Warwick differs markedly from that of its neighbours, Leamington and Stratford-on-Avon. But one should bear in mind that not only does the population of Haute-NormandieSeine Maritime département-differ from that of Basse-NormandieManche, Calvados, Orne, and Eure départements (Khérumian et al., 1959, I960) - but the coastal Normans are much higher in $O$ than the inland Normans (Vallois and Marquer, 1964). And the Norman 
garrison at Warwick may by chance have been heavily weighted with high $O$ people.

\section{The medium A gene frequency}

The two highest $A$ gene frequencies (fig.) occur in Warwickshire and the third lies immediately across the border at Redditch in Worcestershire. The medium $A$ people seem, therefore, to have entered the area under review from the south and south-east and not across the watershed from the Trent in the north.

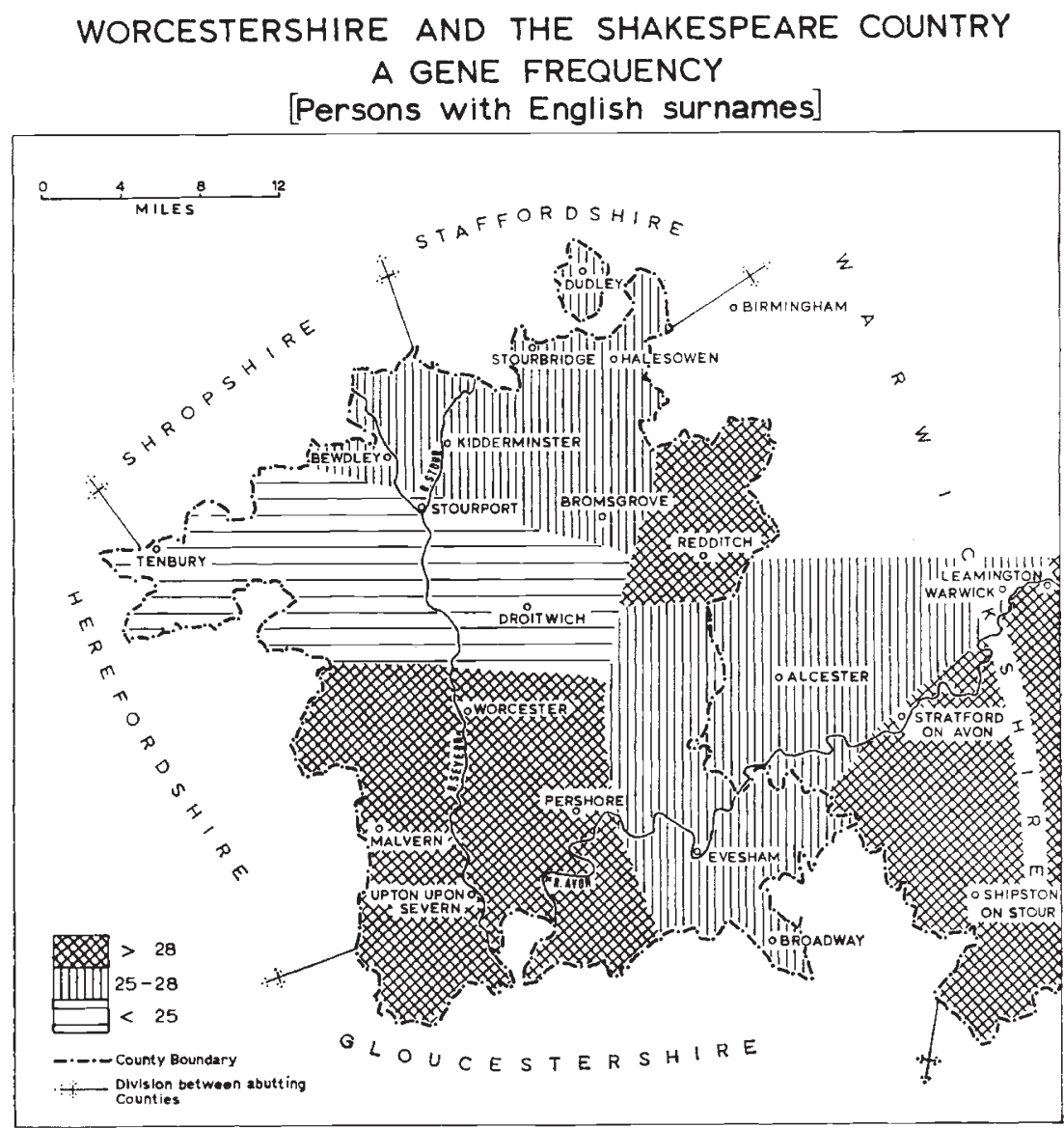

Stenton (1947) claims that the extreme rarity of British place names in Sussex points to English settlement on a scale which left little room for British survival while Hodgkin (I95I) describes the valleys of the Little Ouse and the Lark and the flats extending as far as Cambridge as the chief germinating centre of East Anglia. Sussex (Kopeć, 1956) and East Anglia (Penrose and Penrose, I933) resemble each other in having a population of medium $A$ gene frequency and the continental homelands of the Germanic invaders display a similar characteristic.

Wales, which did not come under the Anglo-Saxon yoke, also 
nurtures in its rural southern parts a population of medium $A$ gene frequency as does Cornwall where Jackson (1953) considers the occupation to have been little more than a scattered settlement of Saxon overlords among a population still fundamentally British. In Cornwall, donors with Cornish surnames are slightly higher in $A$ than the remainder, and in Gloucestershire and northern Wiltshire, donors with Welsh surnames-apparently recent immigrants from South Wales-are somewhat higher in $A$ than the population amongst which they live (Fraser Roberts, I948). Similarly persons with Welsh surnames in eastern Herefordshire have a significantly higher $A$ gene frequency than their English counterparts (Watkin, I965). It seems, therefore, that at least one wave of people of a medium $A$ frequency had invaded Britain before the advent of the Anglo-Saxons and that its gene frequency was higher or its intensity greater than in the AngloSaxon invasions. The raised $A$ gene frequency of southern Worcestershire and south-western Warwickshire cannot be equated with the Anglo-Saxon influx for it may equally well be due to the local survival of old British stocks.

Very high $A$ frequencies suggestive of Scandinavian settlement were not encountered in Worcestershire but it must be borne in mind that the Danish thegns, previously mentioned, formed but a scattered minority.

\section{The B gene frequency}

In Leamington and more markedly so in Warwick the $B$ gene frequency of the population falls below Dobson and Ikin's (1946) average of $6 \cdot 0$ per cent. for England and Wales. Farther south, however, a triad of south-western Warwickshire towns, Stratford-onAvon, Alcester and Shipston-on-Stour are above average in $B$. In Wales a raised $B$ gene frequency, regardless of variations in $O$ and $A$, is a characteristic of all the moorlands where Fleure and James (I9I6) discovered traces of very ancient human stocks (Watkin, I956). Similarly in Ireland, Dawson (1964) observed that the highest $B$ gene frequency occurred in county Roscommon, in the heart of the central boglands. Brown ( 1965 ) noted an association in Scotland between high $B$ frequency areas and the presence of megalithic chambered tombs. It seems on the serological evidence, therefore, that the descendants of some of Britain's earliest inhabitants have survived at Stratford-on-Avon and neighbourhood-a conclusion which Beddoe drew on other anthropological grounds over eighty years ago.

\section{CONCLUSION}

The pattern of the $A B O$ gene frequencies is far more difficult to correlate with physiography in Worcestershire and the Shakespeare country than in Wales or the border counties of Shropshire and Herefordshire. It favours the notion that this part of the Midlands was the meeting point of several human currents-the Anglo-Saxons 
from circa A.D. 550-700 pressing mainly from the south east against an old-established stock, the counter infiltration of the Welsh from the west from about A.D. I 400-I800 except for the years when immigration was prohibited, and the Norman influence on some of the garrison towns.

\section{SUMMARY}

I. The $A B O$ blood-group evidence based on I I,8 I I donors lends no support to the view that the river Severn separates English from Welsh stocks in Worcestershire. Significant $O$ and $A$ differences exist between southern and central Worcestershire, as in Central Wales, and these may form part of a major genetic divide spreading east to west across Britain.

2. Medium $A$ gene frequencies are as likely to point to the presence of old British as to Anglo-Saxon stock but their absence from northern Worcestershire suggests that no strong Anglo-Saxon pressure was exerted across the watershed from the Trent.

3. $B$ gene frequencies above the average for England and Wales at Stratford-on-Avon point to the survival of very old-established human strains.

Acknowledgments.-I wish to thank Dr W. Weiner, Birmingham, the medical director of the National Blood Transfusion Service in the Midland Region, for offering me every facility to analyse the relevant blood-group record cards. Professor C. D. Darlington offered a number of valuable suggestions, as did Professors D. R. Dudley and R. H. Hilton of the University of Birmingham. I am grateful to all three, as I am to my wife who drew the map.

\section{REFERENCES}

(a) History and names

Chitty, Lily, F. 1963. The Clun-Clee Ridgeway: a Prehistoric Trackway across South Shropshire in Culture and Environment-Essays in Honour of Sir Cyril Fox, ed. by I. LL. Foster and L. Alcock. London.

DUdLEy, R. D., AND WEBSTER, G. 1962. The Rebellion of Boudicca. London.

eNDERBIE, P. 1661. Cambria Triumphans. London.

falc'Hun, F. 1963. Histoire de la Langue Bretonne d'après la Géographie Linguistique, 2nd ed. Paris.

Fox, c. 1959. The Personality of Britain, th ed. amended. Cardiff.

HODGKIN, R. H. 1951. A History of the Anglo-Saxons, 3 rd ed. Oxford.

JAGKSON, K. H. 1953. Language and History in Early Britain. Edinburgh.

Lотн, J. 1883. L'émigration Bretonne en Armorique. Paris.

PELhaM, R. A. 1937. The immigrant population of Birmingham, 1686-1726. Trans. Birmingham Arch. Soc., 6I, 45-8o.

REEs, w. 1962. The Evolution of the Welsh Border. O'Donnell Lectures, Univ. of Oxford, 1959-61. Personal Communication.

ROUND, J. H. I9O4. Introduction to the Warwickshire Domesday in Victoria County History of Warwickshire, I, 269-297.

Sergeantson, mary, s. 1927. The Dialects of the West Midlands in Middle English.

Rev. Eng. Studies. 3, 54-67; 186-203; 319-331.

southall, J. E. 1893. Wales and her Language, 2nd ed. Newport and London. STAR CHAMBER PROCEEDINGs, Henry VII, No. 4. Petition by bailiffs and citizens of Worcester that they may take tolls on the Severn with examinations thereon. 
Stenton, F. м. 1947. Anglo-Saxon England, 2nd ed. Oxford.

тномаs, н. J. ig23. The sources of the stones of Stonehenge. Ant. 7., 3, 239-260. TORRINGTON, FifTH Viscount. I 781. Tour to the West. Diaries ed. by C. B. Andrews, 1934. London.

williams, G. 1954. Welshmen in Shakespeare's Stratford. Trans. Hon. Soc. Cymmrodorion, 3 I -59 .

\section{(b) Anthropology and serology}

ANTHRopometric committee of the British Association for the Advancement of Science Report. I883. London.

BEDDOE, J. 1885. The Races of Britain. Bristol.

Brown, ElizabeTh, s. 1965. Distribution of the $A B O$ and Rhesus $(D)$ Blood Groups in the North of Scotland. Heredity, 20, 2, 289-303.

DAwson, G. W. P. 1964 . The frequencies of the $A B O$ and $\mathrm{Rh}(D)$ blood groups in Ireland from a sample of $\mathrm{I}$ in $\mathrm{I} 8$ of the population. Ann. Hum. Genet., Lond., $28,49-59$.

DOBSON, AILEEN, M., AND IKIN, ElizABEth, w. 1946. The $A B O$ blood-groups in the United Kingdom: frequencies based on a very large sample. F. Path. Bact. $58,2,22 \mathrm{I}-227$.

KHÉRUMiAN, R., ROPARTZ, C., AND MOULLEC, J. I959. Répartition des groupes sanguins $A B O$ dans le département de la Seine-Maritime. Rev. d'Haematologie, I4, 5, 418-430.

KHÉRUMiAN, R. I96o. Répartition départementale des groupes sanguins $A B O$ en France métropolitaine. Transfusion, France, 3, 2, 163-180.

KOPEĆ, ADA C. I956. Blood-groups in Great Britain. Advanc. Sci., Lond., 200-203. MOURANT, A. E., KOPÉ́, ADA, C., AND DOMANIEWSKA-SOBGZAK, KAZIMIERA. 1958. The ABO Blood Groups. Oxford.

PENROSE, MARGARET, AND PENROSE, L. S. I 933 . The blood group distribution in the eastern counties of England. Brit. F. exp. Path., I4, I6o-16r.

ROBERTS, J. A. F. I948. The frequencies of the $A B O$ blood-groups in south-western England. Ann. Eugen., Lond., I4, 2, I09-I I 6.

ROBERTS, J. A. F. I953. An analysis of the $A B O$ blood-group records of the North of England. Heredity, 7, 3, 36 $\mathrm{I}-388$.

VALLOIS, H. V., AND MARQUER, PAULETTE, I 964 . La répartition en France des groupes sanguins ABO. Bull. et Mém. de la Soc. d'Anthrop. de Paris, i I S., 6, I-200.

WATKIN, I. M. 1956. $A B O$ blood-groups and racial characteristics in rural Wales. Heredity, Io, 2, I6 I-1 93 .

WATKIN, I. M. 1963. English and Welsh racial elements in western Shropshire and in the adjacent Welsh borderland. 7. R. anthrop. Inst., 94, 52-65.

WATKIN, I. M. I965. $A B O$ blood-groups, human history, and language in Herefordshire with special reference to the low $B$ frequency in Europe. Heredity, 20, I, 83-95. 